77. Fontaine B, Davoine CS, Durr A, et al. A new locus for autosomal dominant pure spastic paraplegia, on chromosome 2q24-q34. Am J Hum Genet 2000;66:702-707.

78. Vazza G, Zortea M, Boaretto F, et al. A new locus for autosomal recessive spastic paraplegia associated with mental retardation and distal motor neuropathy, SPG 14, maps to chromosome 3q27-q28. Am J Hum Genet 2000;67:504-509.

79. Hazan J, Fonknechten N, Mavael D, et al. Spastin, a new AAA protein, is altered in the most frequent form of autoso- mal dominant spastic paraplegia. Nat Genet 1999;23:296303.

80. Casari G, De Fusco M, Ciarmatori S, et al. A. Spastic paraplegia and OXPHOS impairment caused by mutations in paraplegin, a nuclear-encoded mitochondrial metalloprotease. Cell 1998;93:973-983.

81. Auer-Grumbach M, Loscher WN, Wagner K, et al. Phenotypic and genotypic heterogeneity in hereditary motor neuronopathy type V. Brain 2000;123:1612-1623.

\title{
Neuro/mages
}
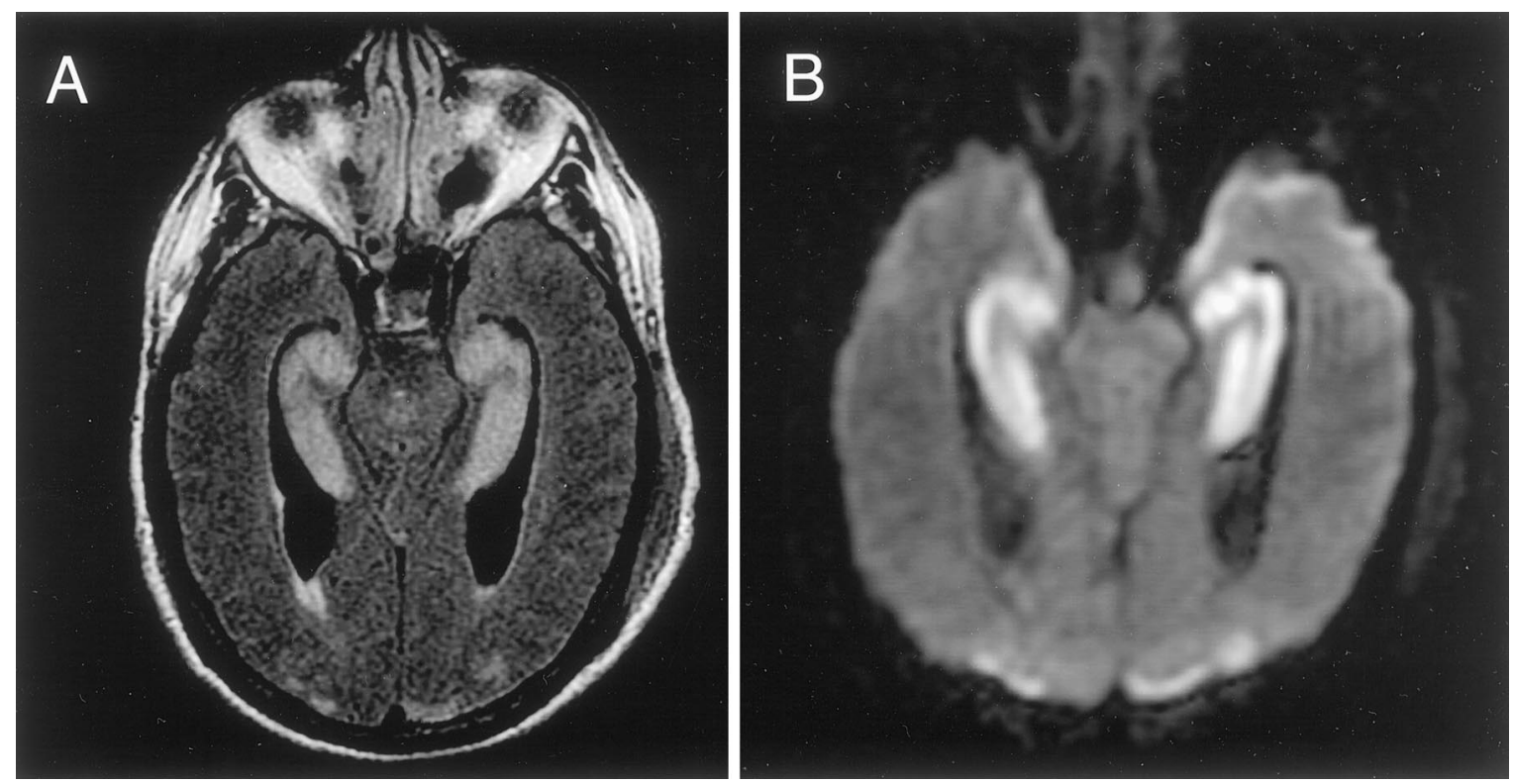

Figure. (A) Axial fluid-attenuated inversion recovery (FLAIR) MRI reveals prominent signal hyperintensity within the medial temporal lobes. (B) In the corresponding diffusion-weighted image, the territory of acute ischemia (high signal intensity) is found to outline the hippocampus bilaterally. Thin rims of hyperintense signal are also present in the temporal poles and occipital cortices.

\section{Carbon monoxide-mediated hippocampal injury}

Jay A. Gottfried, MD, PhD; and Anjan Chatterjee, $M D$, Philadelphia, PA

A 48-year-old man was found unconscious after deliberate carbon monoxide poisoning and flurazepam overdose. His blood pressure was 119/75 mm Hg; his pulse was 102 beats/min, and his respiratory rate was 18 breaths/min. He was intubated, hospitalized, and given $100 \%$ normobaric oxygen for elevated blood carboxyhemoglobin $(9.1 \%)$. He was arousable to voice and had preserved brainstem re- flexes, but no spontaneous movements. Short-term memory loss became apparent when he used eye-blinks to communicate. Infarctions in bilateral hippocampi, temporal poles, occipital cortex (figure), globus pallidi, cerebellum, and brainstem were most consistent with carbon monoxide toxicity. ${ }^{1,2}$ Six months later he is ambulatory, with normal communication but residual anterograde amnesia.

1. O'Donnell P, Buxton PJ, Pitkin A, Jarvis LJ. The magnetic resonance imaging appearances of the brain in acute carbon monoxide poisoning. Clin Radiol 2000;55:273-280.

2. Lapresle J, Fardeau M. The CNS and carbon monoxide poisoning II Anatomical study of brain lesions following intoxication with CO. Prog Brain Res 1967;24:31-74. 


\section{Neurology}

\section{Carbon monoxide-mediated hippocampal injury \\ Jay A. Gottfried and Anjan Chatterjee \\ Neurology 2001;57;17 \\ DOI 10.1212/WNL.57.1.17}

\section{This information is current as of July 10, 2001}

\section{Updated Information \&} Services

References

Citations

Permissions \& Licensing

Reprints including high resolution figures, can be found at: http://n.neurology.org/content/57/1/17.full

This article cites 2 articles, 0 of which you can access for free at: http://n.neurology.org/content/57/1/17.full\#ref-list-1

This article has been cited by 3 HighWire-hosted articles: http://n.neurology.org/content/57/1/17.full\#\#otherarticles

Information about reproducing this article in parts (figures,tables) or in its entirety can be found online at:

http://www.neurology.org/about/about_the_journal\#permissions

Information about ordering reprints can be found online:

http://n.neurology.org/subscribers/advertise

Neurology ${ }^{\circledR}$ is the official journal of the American Academy of Neurology. Published continuously since 1951, it is now a weekly with 48 issues per year. Copyright . All rights reserved. Print ISSN: 0028-3878. Online ISSN: 1526-632X.

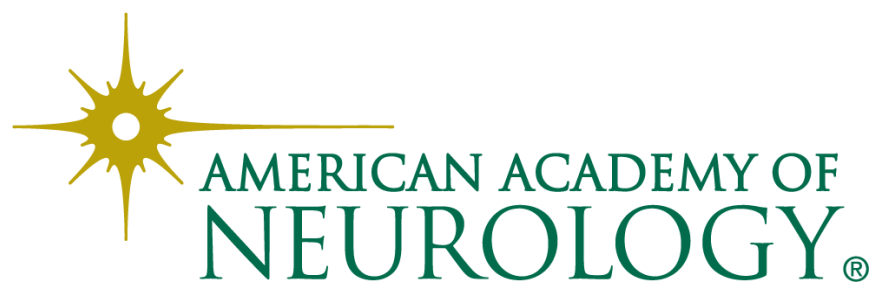

